\title{
Echinacea Inhibits Adenosine Deaminase Enzyme in Cancerous Human Gastric Tissue
}

\author{
Zahide Esra Durak ${ }^{1}$, Hilmi Kocaoğlu ${ }^{2}$, Hikmet Can Çubukçu ${ }^{3}$ and İlker Durak ${ }^{3^{*}}$ \\ ${ }^{1}$ Turkish Heath Ministry, Institute of Public Health Ankara-Turkey \\ ${ }^{2}$ Department of Surgical Oncology Ankara University Faculty of Medicine, Ankara-Turkey \\ ${ }^{3}$ Department of Medical Biochemistry Ankara University Faculty of Medicine, Ankara-Turkey
}

*Corresponding author: İlker Durak, Department of Medical Biochemistry, Ankara University Faculty of Medicine, Ankara-Turkey, Tel: +903125958268; E-mail: ilker_durak@yahoo.com

Received date: Oct 28, 2015; Accepted date: Nov 20, 2015; Published date: Nov 25, 2015

Copyright: @ 2015 Durak I, et al. This is an open-access article distributed under the terms of the Creative Commons Attribution License, which permits unrestricted use, distribution, and reproduction in any medium, provided the original author and source are credited.

\begin{abstract}
Aim: This study aims to investigate the possible effects of aqueous Echinacea (E. Purpurea, whole plant) extract on Adenosine deaminase (ADA) activity in cancerous and non-cancerous human gastric and colon tissues.

Materials and Methods: Thirty three cancerous and 33 non-cancerous human gastric tissues, and 25 cancerous and non-cancerous human colon tissues removed by surgical operations were studied. In the samples, adenosine deaminase activities were measured with and without extract incubation.

Results: It has been observed that Echinacea extract inhibits ADA enzyme in cancerous gastric tissues significantly. It exerts however no inhibitory effects on the ADA activities in the other tissues.

Conclusion: It is proposed that inhibition of ADA enzyme by the Echinacea extract might play part in anti-cancer mechanism of Echinacea in some cancers like gastric cancer.
\end{abstract}

Keywords: Echinacea; Adenosine deaminase

\section{Introduction}

Cancer is a worldwide disease on which great effort is made, and it is still a major problem for all people in the world. The scientists have long been looking to natural remedies for the treatment of cancer because of side effects of classical cancer therapies. Therefore, it has been studied to find medical and nutritional solutions to cure the disease and support the patient's therapy. With the findings that treatment of some types of cancers with plant sources may give rise to positive results, intense effort has been started on possible beneficial potentials of plants in cancer therapy.

There are many factors for cancer process in humans. It has been argued that most of the cancers are caused by environmental factors, and $30-40 \%$ of these cancers are found to be directly linked to the diet [1]. While many dietary recommendations have been proposed to reduce the risk of cancer, unfortunately few have significant supporting scientific evidence [2].

Adenosine deaminase (ADA) is an important enzyme in cancer metabolism (EC 3.5.4.4). It is present almost in all mammalian cells, and its primary function in human beings is thought to be related to the immune system [3]. However, the full physiological role of ADA is not completely understood [4]. ADA association has also been observed with several metabolic events in the body [3,5]. It has also been proposed that $\mathrm{ADA}$, in addition to its role in adenosine breakdown, stimulates release of excitatory amino acids, and functions in the coupling of $\mathrm{Al}$ adenosine receptors and heterotrimeric $\mathrm{G}$ proteins $[3,4]$.
Some chemicals with ADA inhibiting potential have been used for chemoterapeutic purposes in some types of cancers. Use of ADA inhibitors has helped much in understanding the mechanism of action of adenosine metabolites and analogs, and has also led to the understanding of the regulatory processes associated with immunodeficiency characterized by a lack of ADA [6]. Pentostatin (Nipent) is a medicine having potential to inhibit adenosine deaminase enzyme. ADA inhibition blocks the deamination reactions in the purine salvage pathway, result of which is the inhibition of Ribonucleotide reductase. This process depletes the nucleotide pool and limits DNA synthesis [7].

Echinacea is one of the most popular herbs in the world today. Throughout history, people have used Echinacea to treat several diseases including cancer. Today, people use Echinacea to help boost the immune system and help the body fight infections [8]. Echinacea is a perennial plant which belongs to the Asteraceae family [9]. Several classes of active constituents have been identified in Echinacea species including caffeic acid derivatives, alkylamides, polyacetylenes, and polysaccharides which are responsible for the anti-inflammatory, immunostimulatory, antioxidant and cicatrising activities of this plant [10]. Actually, the therapeutic use of Echinacea extracts is mostly for the prevention and treatment of upper respiratory tract infections and influenza symptoms [11-13]. Echinacea preparations are widely used remedies in Complementary and Alternative Medicine [14]. In fact, Echinacea is one of the most popular agent used in cancer patients this use is often an arbitrary choice of the single patient $[15,16]$. Efficacy of Echinacea extracts in anticancer therapy has been proposed to be related to their well-documented immunostimulatory activities due to high molecular weight polysaccharides and alkylamides that, in turn, 
Page 2 of 4

can induce a functional increase of natural killer cells [17,18]. There is evidence suggesting that some phytochemicals in Echinacea might have the capacity to reduce tumors and virus infections [19-25]. The immunostimulating effects of Echinacea in vivo are exclusive to cells mediating spontaneous immunity and their accessory cells [26].

However, to our knowledge, possible effect of Echinacea on human cancer cells, and parameters playing role in cancer metabolism has not been investigated until now. The aim of present study was to investigate possible potential effect of aquoeus Echinacea extract on the ADA enzyme activity in cancerous and non-cancerous human gastric and colon tissues. The subject seems of importance since Echinacea extracts are mostly used in association with conventional chemotherapy in advanced gastroenteric tumors $[27,28]$.

\section{Materials and Methods}

Thirty three cancerous gastric tissues and 33 non-cancerous adjacent gastric tissues were obtained from patients with gastric cancer by surgical operation. Similarly, cancerous and noncancerous colon tissues were obtained from 25 patients with colon cancer. Tissues were first cleaned by saline solution and stored at $-80^{\circ} \mathrm{C}$ until analysis. In the analysis process, they were first homogenized in saline solution $(20 \%$, $\mathrm{w} / \mathrm{v})$. After homogenization, samples were centrifuged at $5000 \mathrm{rpm}$ for $30 \mathrm{~min}$ to remove debris and to obtain clear supernatant fraction. Analyses were performed in this fraction [29].

The extracts were prepared by soaking ground Echinacea powder (E. Purpurea, whole plant) into the distilled water at the concentration of $10 \%(\mathrm{w} / \mathrm{v})$ and waiting for $24 \mathrm{~h}$ at room temperature by continuously rotating. After the debris was removed, supernatants were centrifuged at $10.000 \mathrm{rpm}$ for $20 \mathrm{~min}$ and upper clear part was removed to be used in the assays [30].

Protein concentrations of the tissues were measured by Lowry method [31] and ADA activity was measured by the method of Guisti [32]. Lowry method is based on $\mathrm{Cu}$ - protein complex formation of phosphomolibdic and phosphotungistic acid with the formation of blue colour. ADA activity measurements were performed with and without plant extract for $1 \mathrm{~h}$. This method is based on the measurement of ammonia occurred after deamination reaction by the catlayzing effect of ADA. Statistical evaluations were made by using Wilcoxon test and values lower than 0.05 were evaluated significant.

\section{Results}

Results are shown in the Table 1. As seen from the table, Echinacea extract inhibits ADA enzyme in cancerous gastric tissue significantly but not in noncancerous one. Additionally, it seems that it has also effect on ADA enzyme neither in cancerous nor in noncancerous human colon tissues.

\begin{tabular}{|l|l|}
\hline Malign tisssue & Benign tissue \\
\hline A- $12.1 \pm 7.68$ & $10.20 \pm 8.30$ \\
\hline B- $4.91 \pm 3.03$ & $8.90 \pm 7.02$ \\
\hline C- $5,8 \pm 3.5$ & $5,9 \pm 3.7$ \\
\hline D- $4,6 \pm 2.8$ & $4,9 \pm 3.0$ \\
\hline Statistical evaluation (Wilcoxon test) & \\
\hline A-B: $0.026^{*}$ & 0.32 \\
\hline
\end{tabular}

$$
\text { C-D } 0.36
$$$$
0.22
$$

Table 1: Effects of Echinacea extract on ADA activities in cancerous and non-cancerous human gastric $(n=33)$ and colon tissues $(n=25)$ AGastric tissue ADA activity without extract; B-Gastric tissue ADA activity with Echinacea extract; C-Colon tissue ADA activity without extract; D-Colon tissue ADA activity with Echinacea extract ${ }^{*} \mathrm{p}<0.05$ value was evaluated significant n.s Non-significant.

\section{Discussion}

Nutritional foods are important for the treatment of some types of cancers, leading to the development of potential novel agents. Several of the molecules obtained from foods have been shown to exert anticancer activities on cancer cells. These effects have been observed through in vitro and in vivo animal studies [33-35].

Echinacea purpurea $L$. is one of the medicinal plants widely used for the treatment of several diseases including cancer. It has been reported that Alkylamides of $E$. purpurea extract could effectively enhance phagocytosis of mice alveolar macrophages [36]. In a study, it has been reported that oral administration of Echinacea extracts to mice increases production of anti-inflammatory cytokines IL- 4 and IL-10, but decreases production of TNF- $\alpha$ and IL- $1 \beta$ in spleen cells, suggesting that Echinacea may modulate macrophage function to be anti-inflammatory via a decreased Proinflammatory/Antiinflammatory cytokine ratio [37]. The Immuno-stimulating properties are attributed to the bioactive phytochemicals. Among these, Caffeic acid derivatives, especially Cichoric acid, possess many bioactive functions including Anti-oxidant, Anti-hyaluronidase and antiviral activity etc. [38-40]. Thus, cichoric acid is mostly used as marker to determine the medicinal quality of Echinacea products [41]. It has been found that Echinacea extract exhibits good Antimutagenic activities as well [42].

Despite its well-known immune enhancing role, the effects of Echinacea on cancer cells are still elusive and paradoxical. It has been shown that Echinacea root extracts have cytotoxic effects on pancreatic cancer cell line in a concentration- and time-dependent manner [43].In contrast, other previous studies showed that Echinacea extracts may compromise doxorubicin chemotherapy by promoting cell proliferation in breast and cervical cancer cells [44]. There is a report indicating that daily consumption of Echinacea is prophylactic and significantly alleviates leukemia in mouse model [45]. However, to date, a direct effect of Echinacea extracts on human cancer cells have not been established. In a study, it has been found that the extract of Echinacea has cytotoxic effects on colon cancer cell line [46]. In another study, it has been shown that Cichoric acid in Echinacea extract has a strong growth-inhibitory effect against colon cancer cells, presumably resulting from the reduced telomerase activity and the induction of apoptosis. In this study, it has been pointed out that the exact mechanism of action should still be determined in future studies. Overall, the effects of aqueous Echinacea extract may have provided in vitro evidence for the use as hemotherapeutic agents [47].

In our previous studies, we have found that extracts prepared from some plants like Taxus brefolia [48], Sillybum marianum [49] and Curcuma longa [50] could make significant inhibitions on the ADA activities in cancerous human gastric and colon tissues. In this study, we have also obtained similar results with Echinacea for gastric cancer. As seen from the results (Table 1), Echinacea extract significantly inhibits gastric tissue ADA activity in cancerous tissue, but not in 
noncancerous tissue. Moreover, it exerted no inhibitory potential on the ADA activity in cancerous and noncancerous human colon tissues.

Our results show that aquoeus Echinacea extract can inhibit ADA enzyme in cancerous gastric tissues significantly but does not affect the enzyme activities in the other tissues. It seems quite possible that accumulated adenosine due to the inhibition of ADA enzyme might play an important function in the anti-cancer properties of Echinacea in gastric tissue, possibly through inhibition of Ribonucleotide reductase and depletion of nucleotide pool for new DNA synthesis. This action may result from chemical constituents in the Echinacea extract, which are mainly caffeic acid derivatives, alkylamides, polyacetylenes, and polysaccharides. In fact, these constituents are supposed to have antiinflammatory, immunostimulatory, antioxidant and cicatrising activities. Some other chemicals in Echinacea might also play a part in the inhibiting potential of the plant on the ADA activity in gastric cancer tissue. It would be necessary to carry out further analyses to clarify the matter.

The results of this study also show that effects of Echinacea are not only resulted from its immune system activating potential but also from inhibiting potentials on some key enzymes functioning significant roles in cancer process in some cancerous tissues. Therefore, further researches including cell culture and animal studies are needed to obtain more descriptive information about the subject.

\section{References}

1. Abdulla M, Gruber P (2000) Role of diet modification in cancer prevention. Biofactors 12: 45-51.

2. Food, nutrition, physical activity, and the prevention of cancer: a global perspective (2009) World Cancer Research Fund \& American Institute for Cancer Research.

3. Wilson DK, Rudolph FB, Quiocho FA (1991) Atomic structure of adenosine deaminase complexed with a transition-state analog: understanding catalysis and immunodeficiency mutations. Science 252: 1278-1284.

4. Cristalli G, Costanzi S, Lambertucci C, Lupidi G, Vittori S, et al. (2001) Adenosine deaminase: functional implications and different classes of inhibitors. Med Res Rev 21: 105-128.

5. Aghaei M, Karami-Tehrani F, Salami S, Atri M (2005) Adenosine deaminase activity in the serum and malignant tumors of breast cancer: the assessment of isoenzyme ADA1 and ADA2 activities. Clinical biochemistry 38: 887-891.

6. Glazer RI (1980) Adenosine deaminase inhibitors: their role in chemotherapy and immunosuppression. Cancer Chemother Pharmacol 4: 227-235.

7. Brown JB, Lee G, Grimm GR, Barrett TA (2008) Therapeutic benefit of pentostatin in severe IL-10-/- colitis. Inflamm Bowel Dis 14: 880-887.

8. Sandra CMiller (2005) Evidence-Based Complementary and Alternative Medicine 2: 309-314.

9. Barnes J, Anderson LA, Gibbons S, Phillipson JD (2005) Echinacea species (Echinacea angustifolia (DC.) Hell., Echinacea pallida (Nutt.) Nutt., Echinacea purpurea (L.) Moench.): a review of their chemistry, pharmacology and clinical properties. The Journal of Pharmacy and Pharmacology 57 : 929-954.

10. Speroni E, Govoni P, Guizzardi S, Renzulli C, Guerra MC (2002) Antiinflammatory and cicatrizing activity of Echinacea pallida Nutt. root extract. J Ethnopharmacol 79: 265-272.

11. Chen Y, Fu T, Tao T, Yang J, Chang Y, et al. (2005) Macrophage activating effects of new alkamides from the roots of Echinacea species. J Nat Prod 68: 773-776.

12. Islam J, Carter R (2005) Use of Echinacea in upper respiratory tract infection. South Med J 98: 311-318.
13. Sparreboom A, Cox MC, Acharya MR, Figg WD (2004) Herbal remedies in the United States: potential adverse interactions with anticancer agents. J Clin Oncol 22: 2489-2503.

14. Currier NL, Miller SC (2001) Echinacea purpurea and melatonin augment natural-killer cells in leukemic mice and prolong life span. J Altern Complement Med 7: 241-251.

15. Richardson MA, Sanders T, Palmer JL, Greisinger A, Singletary SE (2000) Complementary/alternative medicine use in a comprehensive cancer center and the implications for oncology. Journal of Clinical Oncology 18: 2505-2514.

16. Dy GK, Bekele L, Hanson LJ, Furth A, Mandrekar S, et al. (2004) Complementary and alternative medicine use by patients enrolled onto phase I clinical trials. J Clin Oncol 22: 4810-4815.

17. Miller SC (2005) Echinacea: a miracle herb against aging and cancer? Evidence in vivo in mice. Evid Based Complement Alternat Med 2: 309-314.

18. Chiccaa A, Adinolfia B, Martinottia E, Foglia S, Breschia MC, et al. (2007) Cytotoxic effects of Echinacea root hexanic extracts on human cancer cell lines. Journal of Ethnopharmacology 110: 148-153.

19. Bauer R (1996) [Echinacea drugs--effects and active ingredients]. Z Arztl Fortbild (Jena) 90: 111-115.

20. Melchart D, Linde K, Worku F, Sarkady L, Holzmann M, et al. (1995) Results of five randomized studies on the immunomodulatory activity of preparations of Echinacea. J Altern Complement Med 1: 145-160.

21. See DM, Broumand N, Sahl L, Tilles JG (1997) In vitro effects of Echinacea and ginseng on natural killer and antibody-dependent cell cytotoxicity in healthy subjects and chronic fatigue syndrome or acquired immunodeficiency syndrome patients. Immunopharmacology 35: 229-235.

22. Roesler J, Emmendorffer A, Steinmuller C, Leuttig B, Wagner H,et al. (1991) Application of purified polysaccharides from cell cultures of the plant Echinacea purpurea to test subjects mediating activation of the phagocyte system. Int J Immunopharmacol 13: 931-941.

23. Roesler J, Steinmüller C, Kiderlen A, Emmendörffer A, Wagner H, et al. (1991) Application of purified polysaccharides from cell cultures of the plant Echinacea purpurea to mice mediates protection against systemic infections with Listeria monocytogenes and Candida albicans. Int J Immunopharmacol 13: 27-37.

24. Steinmuller C, Roesler J, Grottrup E, Franke G, Wagner H, et al. (1993) Polysaccharides isolated from plant cell cultures of Echinacea purpurea enhance the resistance of immunosuppressed mice against systemic infections with Candida albicans and Listeria monocytogenes. Int J Immunopharmacol 15: 605-614.

25. Luettig B, Steinmüller C, Gifford GE, Wagner H, Lohmann-Matthes ML (1989) Macrophage activation by the polysaccharide arabinogalactan isolated from plant cell cultures of Echinacea purpurea. J Natl Cancer Inst 81: 669-675.

26. Sun LZ, Currier NL, Miller SC (1999) The American coneflower: a prophylactic role involving nonspecific immunity. J Altern Complement Med 5: 437-446.

27. Lersch C, Zeuner M, Bauer A, Siemens M, Hart R, et al. (1992) Classen Nonspecific immunostimulation with low doses of cyclophosphamide (LDCY), thymostimulin, and Echinacea purpurea extracts (echinacin) in patients with far advanced colorectal cancers: preliminary results. Cancer Investigation 10: 343-348.

28. Lersch C, Gain T, Lorenz R, Classen M (1994) [Chemoimmunotherapy of malignancies of the gastrointestinal tract]. Immun Infekt 22: 58-59.

29. Durak I, Biri H, Ergüder I, Devrim B, Senocak E, et al. (2007) Effects of garlic and black grape extracts on the activity of adenosine deaminase from cancerous and noncancerous human urinary bladder tissues. Medicinal Chemistry Research 16: 259-265.

30. Zahide E, Durak, Suleyman Buber, Ender H (2015) Kocaoglu, Bahadir Ozturk. American Journal of Food Science and Health 1: 51-56.

31. LOWRY OH, ROSEBROUGH NJ, FARR AL, RANDALL RJ (1951) Protein measurement with the Folin phenol reagent. J Biol Chem 193: 265-275. 
Citation: Durak ZE, Kocaoglu H, Çubukçu HC, Durak I (2015) Echinacea Inhibits Adenosine Deaminase Enzyme in Cancerous Human Gastric Tissue. J Carcinog Mutagene 6: 246. doi:10.4172/2157-2518.1000246

Page 4 of 4

32. Guisti G (2011) Enzyme activities. Methods of enzymatic analysis. Weinheim Bergest: Verlag chemia, 1087-1091, 1974.

33. Chang CJ, Ashendel CL, Geahlen RL, McLaughlin JL, Waters DJ (1996) Oncogene signal transduction inhibitors from medicinal plants. In Vivo 10: $185-190$.

34. Desai AG, Qazi GN, Ganju RK, El-Tamer M, Singh J, et al. (2008) Medicinal plants and cancer chemoprevention. Curr Drug Metab 9: 581-591.

35. Lee HZ, Hsu SL, Liu MC, Wu CH (2001) Effects and mechanisms of aloeemodin on cell death in human lung squamous cell carcinoma. Eur J Pharmacol 431: 287-295.

36. Goel V, Chang C, Slama JV, Barton R, Bauer R, et al. (2002) Alkylamides of Echinacea purpurea stimulate alveolar macrophage function in normal rats Int Immunopharmacol 2: 381-387.

37. Zhai Z, Liu Y, Wu L, Senchina DS, Wurtele ES, et al. (2007) Enhancement of innate and adaptive immune functions by multiple Echinacea species. J Med Food 10: 423-434.

38. Bauer R, Wagner H, (1991) Echinacea species as potential immunostimulating drugs. In: Wagner $H$, Farnsworth NR (eds.), Economic and Medicinal Plant Research 5: 253-321.

39. Pellati F, Benvenuti S, Magro L, Melegari M, Soragni F (2004) Analysis of phenolic compounds and radical scavenging activity of Echinacea spp. J Pharm Biomed Anal 35: 289-301.

40. Barnes J, Anderson LA, Gibbons S, Phillipson JD (2005) Echinacea species (Echinacea angustifolia (DC.) Hell., Echinacea pallida (Nutt.) Nutt., Echinacea purpurea (L.) Moench): a review of their chemistry, pharmacology and clinical properties J Pharm Pharmacol 57: 929-954.

41. Thygesen L, Thulinn J, Mortensen A, Skibsted LH, Molgaard P (2007) Antioxidant activity of cichoric acid and alkamides from Echinacea purpurea, alone and in combination. Food Chemistry 101: 74-81.

42. Tsai YL, Chiou SY, Chan KC, Sung JM, Lin SN (2012) Caffeic acid derivatives, total phenols, antioxidant and antimutagenic activities of
Echinaceapurpurea flower extracts. LWT-Food Science and Technology 46: $169-176$

43. Chicca A, Adinolfi B, Martinotti E, Fogli S, Breschi MC, et al. (2007) Cytotoxic effects of Echinacea root hexanic extracts on human cancer cell lines. J Ethnopharmacol 110: 148-153.

44. Huntimer ED, Halaweish FT, Chase CC Proliferative activity f Echinacea angustifolia root extracts on cancer cells: interference with doxorubicin cytotoxicity Chemistry and Biodiversity 3: 695-703.

45. Miller SC (2005) Echinacea: a miracle herb against aging and cancer? Evidence in vivo in mice. Evid Based Complement Alternat Med 2: 309-314.

46. Chicca A, Adinolfi B, Martinotti E, Fogli S, Breschi MC, et al. (2007) Cytotoxic effects of Echinacea root hexanic extracts on human cancer cell lines. J Ethnopharmacol 110: 148-153.

47. Yu-Ling Tsai, Chien-Chih Chiu, Jeff Yi-Fu Chen, Kung-Chi Chan, ShengDun Lin (2012) Cytotoxic effects of Echinacea purpurea flower extracts and cichoric acid on human colon cancer cells through induction of apoptosis. J Ethnopharmacol 143: 914-919.

48. Durak ZE, Büber S, Devrim E, Kocaoglu H, Durak I (2014) Aqueous extract from taxus baccata inhibits adenosine deaminase activity significantly in cancerous and noncancerous human gastric and colon tissues. Pharmacogn Mag 2: S214-S216.

49. Öztürk B, Kocaoglu EH, Durak ZE (2015) Effects of aqueous extract from Silybum marianum on adenosine deaminase activity in cancerous and noncancerous human gastric and colon tissues. Pharmacogn Mag 11: 143-146.

50. Zahide Esra Durak, Süleyman Buber, Erdinç Devrim, Hilmi Kocaoglu, Ilker Durak (2015) Aquoeus extract from curcuma longa inhibits adenosine deaminase activity significantly in cancerous and noncancerous human gastric and colon tissues. Food and Nutrition Report 1 : 1-3. 